\title{
Role of animal power in the field of agriculture
}

\section{Commentary}

Draught animal power has traditionally been the main source of power in Indian agriculture. ${ }^{1}$ India is blessed with over 73 million draught animals which account for equivalent to 18 million $\mathrm{kw}$. Among the draught animals the bullocks, buffaloes and camels are extensively used for draft purposes, whereas, the horses, mules/ donkeys and camels are employed as pack animals. Draught animals (DAs) have contributed a great deal to the development of civilisation. Even in this century, when petroleum-based mechanical and electrical equipment has replaced animals in advanced countries, DAs still play an important role in certain developing countries, and will probably continue to do so for many years. DAs are used for agriculture operations like tillage, seedbed preparation, sowing, weeding, and harvesting, threshing and post-harvest operations. Greater care of draught animals will also improve human welfare. Most animal welfare organisations are largely concerned with pet animals and wildlife. Although livestock and DAs are included in the work of these organisations, very little attention is actually paid to draught animals. Small and marginal farmers, who have $80 \%$ operational holdings, are the major users of animal power. It is estimated that nearly $60 \%$ of the total draft power used in agriculture is still provided by animal. A draft animal can exert about one-tenth (1/10) of its body weight for doing farm work. But for a very short period, it can exert many more times the average force. Power developed by an average pair of bullock is about 750 watts (about $1 \mathrm{hp}$ ) for usual farm work. ${ }^{2}$

The utilization of animals for draught purposes as well as power developed by them depends mainly on characteristics of animals (breed, species, sex, age, training and temperament). Also, it depends

Table I Average utilization of draught animal power on Indian farms
Volume 3 Issue I - 2018

\author{
Ashulata Netam, Payal Jaiswal \\ University in Raipur, India
}

Correspondence: Ashulata Netam, Scholar, University in Raipur, India, Email ashulnetam@gmail.com

Received: December 28, 2017| Published: January 24, 2018

on how they are tamed, trained and harnessed. There are various types of harnesses that can be classified according to the place where they are applied, e.g. before the shoulders (collar), on the withers (withers yoke), just behind the horns on the neck (neck yoke) or on the breast (breast band or breast strap). In India, the use of improved yoke has made it possible to achieve $16-30 \%$ increase in draught capacity under sustain loading and $20-30 \%$ increase in field capacity of implements, resulting in increase in command area of draught animals, compared to traditional yokes. Hence, selection of matching improved implements coupled with efficient harnessing would definitely enhance the power output. Draught Animals will continue to exist in Indian economy till such time that milk is considered essential for human consumption. These animals are responsible for saving petroleum worth Rs. 2,15,000 million. This is over and above the economic benefits derived in terms of biomass and hide generated from draught animals. The use of buffaloes in mechanized region of Northern foot hills, is about 480 hours a year. ${ }^{3}$ However, in other regions, the bullocks are put to use to an extent of about 230-280hrs. On the other hand, the dry desert region of Western India, Press the camel to work for about $1200 \mathrm{hrs}$ (Table 1).

\begin{tabular}{llll}
\hline S No & Location & Average annual utilization $(\mathbf{H r s})$ & Maximum utilization \\
\hline 1 & North & 660 & Transport \\
2 & South & 230 & Tillage \& Seeding \\
3 & East & 450 & Tillage \& Seeding \\
4 & West & 500 & Tillage \& Seeding \\
5 & Central & 280 & Tillage \& Seeding \\
\hline
\end{tabular}

It is because of that the animals should not be put work for a very long duration without permitting them to take rest. The most preferred work rest cycles for the Draught animals were noticed as follows:

a. Bullocks: $3 \mathrm{hr}$ work $+1 \mathrm{hr}$ rest $+3 \mathrm{hr}$ or $4 \mathrm{hr}$ work $+2 \mathrm{hr}$ rest $+3 \mathrm{hr}$ work.

b. Buffaloes: $4 \mathrm{hr}$ work in the morning $+2 \mathrm{hr}$ rest $+4 \mathrm{hr}$ work in the evening.

c. Camels: $2 \mathrm{hr}$ work $+1 \mathrm{hr}$ rest $+2 \mathrm{hr}$ work $+1 \mathrm{hr}$ rest $+2 \mathrm{hr}$ work.

d. Donkeys: 1 hr work $+1 \mathrm{hr}$ rest $+1 \mathrm{hr}$ work $+1 \mathrm{hr}$ rest and so on up to $6 \mathrm{hr}$ of work/day.

If the longer duration work is required, the draught and speed have to be kept low. The combination of draught, speed and duration of work causes the onset of fatigue in work animals. If no proper balance is maintained among these three basic parameters, animals are likely to get excessive fatigue. In addition, climatic factors namely atmospheric temperature and relative humidity also greatly influenced the work capacity and fatigue of animals. A hot and humid climate is known to cause early fatigue, followed by hot and cold climate.

\section{Improving draught animal welfare}

Throughout their working life, Das are subjected to a variety of inadequacies which could be prevented by instituting measures such as the following:

a. Appropriate and sufficient feed to ensure health and growth, as well as energy for work 
b. Adequate health care and prompt provision of veterinary services in case of injuries and sickness, and to aid resistance to disease

c. Appropriate well-fitting equipment for working, prevention of injury while working, etc.

d. Prevention of overstraining, allowing Das to rest from work while sick of injured, and avoiding putting animals to work in adverse ambient conditions

e. Ensuring observance of laws to prevent the misuse and abuse of draught animals.

f. Use of modern equipment and methods for surgical treatments and slaughter

g. Allowing animals, the freedom to satisfy natural instincts

h. Adoption of human methods for nose-roping, shoeing, branding, dehorning, etc.

i. Development of publicity and education programmes by animal welfare organisations.

\section{Machine Vs draught animal}

The cropping season generally lasts for only about 30 days during Kharif and 30 days during Rabi or total of 60 days in year 70million bullocks exclusively used over 60 days, for cultivation, $6 \mathrm{hr}$ each day, account for a total output of about 9450 million $\mathrm{KWH}$ or power units work animals are used only for 100 days in a year for all purposes together (cultivation and transportation). Their total work output for the 100day period. The average working year for a work bullock would be 15750 million KWH or units. ${ }^{4}$

\section{Feed and nutrition}

Farmers should feed concentrates to draught animals, to provide energy for work. However, the common practice to feed straw from paddy fields, wheat or other cereals, or millet. These foods often affect the nutritional status of animals, since the high oxalic acid content of straw removes calcium from the body. This is commonly attributed reason for the often-emaciated condition of animals in countries where rice cultivation is dominant. Policies concerning raw material for concentrates may reduce the availability of commercial feed for draught animals. Therefore, policies on the production of oil-seed and other raw materials needed by the animal feed industry should be integrated, so that the animal feed sector does not suffer unduly.

\section{Acknowledgements}

None.

\section{Conflict of interest}

The author declares no conflict of interest.

\section{References}

1. Singh G. Draught animal energy research in India. India: Central Institute of Agricultural Engineering; 1999.

2. Ramaswamy NS. Draught animals and welfare. Rev Sci Tech. 1994;13(1):195-216.

3. Phaniraja KL, Panchasara HH. Indian draught animal power. Veterinary World. 2009;2(10):404-407.

4. Micheal AM, Ojha TP. Principles of Agricultural Engineering. 2nd ed. India: Jain brothers; 2017. 